\title{
Early acute otitis media and siblings' attendance at nursery
}

Kari J Kværner, Per Nafstad, Jørgen A Hagen, Iain W S Mair, Jouni J K Jaakkola

\begin{abstract}
To assess the relation between early acute otitis media and exposure to respiratory pathogens mediated by siblings and other children, a prospective cohort of 3754 Norwegian children born in 1992-3 was followed up from birth to 12 months. Of these, $25 \%$ had one or more episodes of acute otitis media during the first year. Results from multiple logistic regression analysis adjusted for confounding showed that siblings' attendance at daycare is the most important risk factor for early acute otitis media (adjusted odds ratio, $\mathbf{O R}_{\mathrm{adj}}=$ 1.9). The total number of children in the daycare setting is another determinant for early acute otitis media $\left(O R_{\mathrm{adj}}=\mathbf{2 . 0}\right.$ in groups of four or more other children and $O R_{\text {adj }}=1.3$ in groups of one to three other children, as compared to those who are cared for alone). Having siblings in daycare outside the home and the number of children in the daycare setting are the most important determinants for early acute otitis media.

(Arch Dis Child 1996;75:338-341)
\end{abstract}

Keywords: acute otitis media, daycare, siblings.

Acute otitis media is common among children. ${ }^{2}$ Single infectious episodes are relatively easy to manage, but children with recurrent acute otitis media represent a clinical challenge. ${ }^{3}$ Because of the medical and social costs associated with otitis media and its possible impact on language development, efforts have been made to identify the causes for this disorder. The finding that otitis media tends to cluster in families suggests that genetic factors influence the susceptibility for the disease, ${ }^{45}$ but environmental factors, such as daycare attendance and family size, are quite consistently reported to be determinants for acute otitis media. ${ }^{6-11}$ If the degree of exposure to viral and bacterial antigens in daycare is associated with the total number of primary contacts with other children, the risk for otitis media should be related to the number of children in the daycare setting. Also, siblings in daycare outside the home most probably act as carriers of viral and bacterial antigens acquired in daycare, and cause an increased exposure to respiratory pathogens for the infant at home.

For this study, we used data from a prospective birth cohort of Oslo-born children to examine the relation between acute otitis media before the age of 1 year and the degree of exposure to respiratory pathogens. Due to the long Norwegian maternity leave (42 weeks) and the custom of keeping siblings in their present daycare arrangement while caring for the newborn at home, the cohort offered a unique opportunity to study the impact of secondary infectious exposure transmitted by siblings in daycare. Firstly we estimated the extent to which the presence of siblings in daycare is a risk factor for acute otitis media in the first year of life. Second, to assess whether closeness to the carrier of the infectious agents is important, the risk for acute otitis media was compared between children who shared bedrooms and those who slept in separate bedrooms. Finally, we estimated whether the total number of children in daycare is another determinant for acute otitis media in infancy.

\section{Methods}

STUDY POPULATION AND DATA COLLECTION

The source population included children born in the two main birth clinics in Oslo during a 15 month period in 1992-3. The eligibility criteria were: permanent address within the city of Oslo, no plans for moving from Oslo within the near future, birth weight greater than $2000 \mathrm{~g}$, no serious illness which might impair respiration, at least one Norwegian speaking family member, at least one biological parent, and no drug abuse in the family. Of 4973 eligible children, 3754 (75\%) entered the study. Their parents were asked to fill in a self administered questionnaire on health and environment during pregnancy. Exclusions were mainly due to language problems: immigrants $(\mathrm{n}=1045)$, address outside Oslo ( $\mathrm{n}=$ $180)$, and low birth weight $(n=160)$. Comparisons between those who entered the study and non-participants showed no substantial differences in birth weight, maternal age, maternal history of allergy, and percentage of families with first born child. However, smoking during early pregnancy was more common among nonparticipating mothers. When the child was aged 6 and 12 months, questionnaires regarding the child's health and environmental exposures were posted to the families. The numbers of respondents at the follow up at 6 and 12 months were 3563 and 3452 , which are respectively $95 \%$ and $92 \%$ of the initial participants. The children in the 6 months and 1 year cohorts did not differ substantially from those who entered the study in terms of birth weight, maternal smoking rate at the end of pregnancy, maternal education, and family income per year.

OUTCOME MEASURES, EXPOSURE ASSESSMENT, AND COVARIATES

Acute otitis media was the outcome of interest. The infectious episodes were regarded as acute

Oslo, Norway. 
otitis media if they had been diagnosed as such by the primary physician. The dates and total number of infections were obtained from the 6 and 12 month questionnaires. To define a new episode of acute otitis media, an intermediate period of at least one month was required.

Other children were considered to be the main transmitting source of infectious exposure causing acute otitis media. Using data from the 6 and 12 month questionnaires, siblings were categorised into primary and secondary carriers of pathogens. The primary contact category included both siblings in the family and the other children in the child's daycare arrangement, and was quantified by the number of children. For this study, the child care arrangement had to be more than 10 hours a week. If siblings attended daycare outside the home, the transmitting source represented a secondary contact category. Based on this classification, the following sibling contact categories were defined: (1) no siblings; (2) sibling(s), not in daycare, and (3) sibling(s) in daycare. Whether the siblings shared bedrooms or not represented the closeness of the primary contact.

Table 1 Characteristics of the Oslo birth cohort by contact category. The numbers are given as the percentage of affected participants in each of the risk categories described below

\begin{tabular}{|c|c|c|c|c|}
\hline & \multicolumn{3}{|c|}{ Contact category ${ }^{l}$} & \multirow[b]{2}{*}{$\begin{array}{l}1 \text { year cohort } \\
(n=3238)\end{array}$} \\
\hline & $\begin{array}{l}\text { No siblings } \\
(n=1658)\end{array}$ & $\begin{array}{l}\text { Siblings, not in } \\
\text { daycare } \\
(n=405)\end{array}$ & $\begin{array}{l}\text { Siblings, in } \\
\text { daycare } \\
(n=1085)\end{array}$ & \\
\hline $\begin{array}{l}\text { Gender (male) }{ }^{2} \\
\text { Birth weight }{ }^{2}\end{array}$ & 54 & 47 & 51 & 52 \\
\hline $\begin{array}{l}<2500 \mathrm{~g} \\
2500-3499 \mathrm{~g} \\
+3500 \mathrm{~g}\end{array}$ & $\begin{array}{r}2 \\
47 \\
51\end{array}$ & $\begin{array}{r}5 \\
42 \\
53\end{array}$ & $\begin{array}{r}1 \\
35 \\
64\end{array}$ & $\begin{array}{r}2 \\
42 \\
56\end{array}$ \\
\hline $\begin{array}{l}\text { Season of birth }{ }^{2} \\
\text { January-March } \\
\text { April-June } \\
\text { July-August } \\
\text { September-December }\end{array}$ & $\begin{array}{l}23 \\
26 \\
28 \\
23\end{array}$ & $\begin{array}{l}26 \\
24 \\
27 \\
24\end{array}$ & $\begin{array}{l}23 \\
30 \\
35 \\
23\end{array}$ & $\begin{array}{l}23 \\
27 \\
27 \\
23\end{array}$ \\
\hline $\begin{array}{l}\text { Maternal education } \\
<12 \text { years } \\
12-15 \text { years } \\
>15 \text { years }\end{array}$ & $\begin{array}{r}6 \\
41 \\
54\end{array}$ & $\begin{array}{l}12 \\
46 \\
43\end{array}$ & $\begin{array}{r}4 \\
34 \\
62\end{array}$ & $\begin{array}{r}6 \\
39 \\
55\end{array}$ \\
\hline Single parenthood at birth ${ }^{2}$ & 7 & 4 & 2 & 5 \\
\hline $\begin{array}{l}\text { Family income per year }{ }^{3} \\
<200000 \mathrm{Nkr} \\
200000-500000 \mathrm{Nkr} \\
>500000 \mathrm{Nkr}\end{array}$ & $\begin{array}{l}18 \\
66 \\
16\end{array}$ & $\begin{array}{l}16 \\
67 \\
18\end{array}$ & $\begin{array}{r}8 \\
68 \\
24\end{array}$ & $\begin{array}{l}14 \\
64 \\
19\end{array}$ \\
\hline $\begin{array}{l}\text { Family history of allergic } \\
\text { rhinitis }^{2}\end{array}$ & 28 & 28 & 30 & 29 \\
\hline $\begin{array}{l}\text { Maternal smoking at } 6 \\
\text { months }^{2}\end{array}$ & & & & \\
\hline $\begin{array}{l}\text { No } \\
\text { Occasional } \\
1-14 \text { cig per day } \\
>14 \text { cig per day }\end{array}$ & $\begin{array}{r}73 \\
8 \\
15 \\
5\end{array}$ & $\begin{array}{r}71 \\
7 \\
14 \\
7\end{array}$ & $\begin{array}{r}76 \\
8 \\
11 \\
5\end{array}$ & $\begin{array}{r}74 \\
8 \\
13 \\
5\end{array}$ \\
\hline $\begin{array}{l}\text { Duration of breastfeeding }{ }^{2} \\
0-6 \text { months } \\
\text { 7-12 months }\end{array}$ & $\begin{array}{l}32 \\
67\end{array}$ & $\begin{array}{l}34 \\
65\end{array}$ & $\begin{array}{l}26 \\
74\end{array}$ & $\begin{array}{l}31 \\
69\end{array}$ \\
\hline $\begin{array}{l}\text { Child care at one year by } \\
\text { group size } \\
\text { No other children } \\
1-3 \text { other children } \\
4 \text { or more other children }\end{array}$ & $\begin{array}{l}61 \\
25 \\
14\end{array}$ & $\begin{array}{r}82 \\
9 \\
8\end{array}$ & $\begin{array}{l}73 \\
11 \\
16\end{array}$ & $\begin{array}{l}68 \\
18 \\
14\end{array}$ \\
\hline
\end{tabular}

90 participants with missing information about contact category.

0-50 missing.

3 51-100 missing.

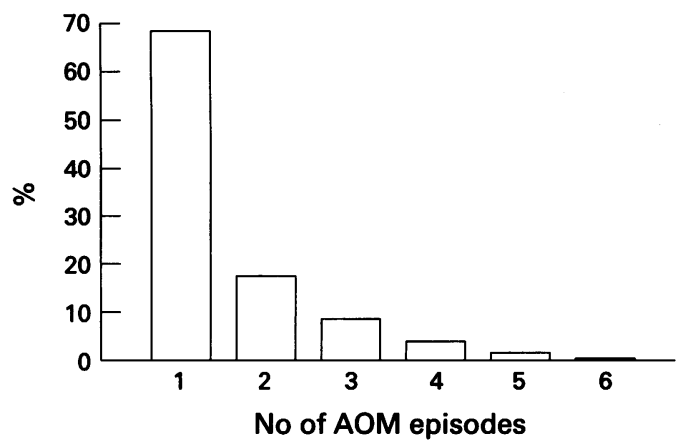

Figure 1 Frequency of distribution of the number of acute otitis media episodes among the children.

Information on covariates was collected from the enrolment of the child and from the 6 month and 12 month follow up questionnaires. The distribution of the covariates by the sibling contact category is presented in table 1 .

\section{STATISTICAL ANALYSIS}

Cumulative incidences were used to describe the risk for acute otitis media by contact categories and child care setting. The odds ratio (OR) was used as a measure of association between the occurrence of acute otitis media and the type of contacts. The adjusted odds ratios were estimated in logistic regression analysis using SPSS 6.1, controlling for the covariates in table 1 . Based on previous knowledge five core covariates (gender, breast feeding, exposure to environmental tobacco smoke, family income, and maternal education) were always included in the model. The other covariates were included if their inclusion had an impact on the accuracy and precision of the estimate of the studied relation. ${ }^{12}$ The various secondary contact categories were contrasted to the reference category defined as siblings. To assess whether closeness to the primary contact was important, the sibling categories were stratified into those who shared bedrooms and those who slept alone. The role of the primary contact was assessed using three categories based on the total number of other children: (1) none, (2) one to three, and (3) four or more children (table 3). Category 1 included both the children who were still cared for at home and those who were cared for by a babysitter. When the role of the primary contact was assessed, the study population was restricted to the children without siblings in day care outside the home, that is, without secondary contacts. In the a priori power calculations the size of the cohort would be sufficient to detect a cumulative incidence difference of 0.10 among the sibling and daycare contact categories with $\alpha=0.05$ and $\beta=0.20$.

\section{Results}

Twenty five per cent (815) of the children experienced at least one acute otitis media episode before 1 year of age. Mean age at the first infection was 8 months (range 1 to 12). Figure 1 figure shows the distribution of otitis media by the number of infections in each child. In bivariate analyses significant associations were found between otitis media and both siblings in 
Table 2 Cumulative incidence (CuI), crude ORs (cOR), adjusted $\left(O R_{\text {adi }}\right)$, and $95 \%$ confidence intervals (CI) for acute otitis media during the first 12 months by sibling attendance at daycare. Reference category is children without siblings

\begin{tabular}{lllll}
\hline Contact category by 12 months & $n$ & CuI & cOR & $O_{\text {adj }}(95 \%$ CI) \\
\hline No siblings & 1658 & 0.21 & $\operatorname{Ref}^{1}$ & \\
Sibling(s), not in daycare & 405 & 0.25 & 1.2 & $1.3(1.0$ to 1.7$)$ \\
Sibling(s), in daycare & 1085 & 0.32 & 1.8 & $1.9(1.4$ to 2.3$)$ \\
\hline
\end{tabular}

${ }^{1}$ Ref $=$ reference category.

Adjusted ORs are controlled for gender, birth weight, season of birth, maternal education, family income per year, single parenthood, breast feeding at 6 months, maternal smoking at 6 months, and number of children in daycare.

daycare and the total number of children in daycare $\left(\chi_{4}^{2}=42.4, \mathrm{p}<0.01\right.$ and $\chi_{2}^{2}=18.2$, $\mathrm{p}<0.01$, respectively). There was a nonsignificant tendency for a higher cumulative incidence of otitis media among boys than among girls $\left(\chi^{2}=2.1, \mathrm{p}=0.14\right)$. No significant associations were found between acute otitis media and breast feeding, maternal smoking, or socioeconomic conditions.

INFECTIOUS EXPOSURE MEDIATED BY SIBLINGS IN DAYCARE

The results from the logistic regression analysis in table 2 show that children with siblings attending daycare have an almost twofold increased risk for acute otitis media. Having siblings, but not in daycare, also confers a greater risk for otitis media as compared to children without siblings. The risk associated with siblings in daycare is over twofold during the first 6 months of life $\left(O R_{\mathrm{adj}}=2.7\right.$ (2.0 to 3.7)) and becomes somewhat reduced from 6 to 12 months $\left(\mathrm{OR}_{\mathrm{adj}}=1.6(1.3\right.$ to 2.0$\left.)\right)$. No differences in relative risks due to siblings in daycare were found between the children who shared bedrooms and those with separate bedrooms $\left(\mathrm{OR}_{\mathrm{adj}}=1.4(0.9\right.$ to 2.0$)$ and $\mathrm{OR}_{\mathrm{adj}}=$ 1.2 (0.5 to 2.8 ), respectively).

INFECTIOUS EXPOSURE MEDIATED BY NUMBER OF CHILDREN IN DAYCARE SETTING

The 1347 children without siblings in daycare who were cared for alone at home $(n=366)$ or by a babysitter $(n=981)$ constituted the reference. The risk for acute otitis media was related to group size (table 3 ). With four or more children in the daycare setting, there is a twofold risk increase for acute otitis media. No significant differences were found between the various forms of daycare arrangements when adjustment was made for group size.

\section{Discussion}

In our study, having siblings in daycare and the total number of children in own daycare setting were the main risk factors for early acute otitis media. Siblings who attend daycare most likely act as secondary carriers of viral and bacterial antigens acquired in daycare, while greater numbers of children in the daycare setting probably increase the primary infectious exposure. Because early age of the initial acute otitis media episode is considered important for the later development of recurrent acute otitis
Table 3 Cumulative incidence (CuI), crude ORs (cOR), adjusted $O R s(O R$ ) and 95\% confidence intervals (CI) for acute otitis media during the first 12 months by number of other children in childcare. Reference category is daycare setting with no other children. The study population is restricted to the children without siblings in daycare $(n=2063)$

\begin{tabular}{|c|c|c|c|c|}
\hline $\begin{array}{l}\text { Daycare category by } 12 \\
\text { months }\end{array}$ & $n$ & $C u I$ & $c O R$ & $\begin{array}{l}O R_{a d j}(95 \% \\
C I)\end{array}$ \\
\hline $\begin{array}{l}\text { No other children } \\
1-3 \text { other children }\end{array}$ & $\begin{array}{l}1347 \\
447\end{array}$ & $\begin{array}{l}0.19 \\
0.24\end{array}$ & $\begin{array}{l}\operatorname{Ref}^{1} \\
1.3\end{array}$ & $\begin{array}{l}1.3(1.0 \text { to } \\
1.7)\end{array}$ \\
\hline $\begin{array}{l}4 \text { or more other } \\
\text { children }\end{array}$ & 269 & 0.31 & 1.6 & $\begin{array}{l}2.0(1.4 \text { to } \\
2.6)\end{array}$ \\
\hline
\end{tabular}

${ }^{1}$ Ref $=$ reference category

Adjusted ORs are controlled for gender, birth weight, season of birth, maternal education, family income per year, single parenthood, breast feeding at 6 months, maternal smoking at 6 months, and the presence of siblings in daycare.

media, determinants for early acute otitis media should be identified. ${ }^{4}$ Daycare is quite consistently reported to be the major risk factor. It is not clear, however, whether daycare centres provide an additional transferral of pathogens between the staff and the children, or-as the present study finds evidence forwhether the risk is only related to group size. $^{6-810111314}$ Furthermore, some studies report that acute otitis media is related to the number of siblings, ${ }^{914}$ while others find siblings with an otitis media history to increase the risk for acute otitis media. ${ }^{45}$ The latter group may exert an effect through a common genetic predisposition or by acting as transmitters of a larger loading of respiratory pathogens. Because older siblings are kept in daycare outside the home during the long Norwegian maternity leave, the cohort provided an opportunity to study the impact of pathogen transmission from siblings in daycare. In addition to a possible genetic predisposition, environmental factors, such as increased exposure to respiratory pathogens mediated by siblings, should be considered in familial aggregation of acute otitis media.

\section{VALIDITY OF RESULTS}

Because of the prospective cohort design, the high follow up rate $(86 \%)$, and the similarity between the participants in the cohort and those in the follow up, selection bias is not a likely explanation for the observed associations. Introduction of bias due to differences in parental health behaviour or availability of health care related to daycare was unlikely because Norwegian health services for children are free. Also, it is unlikely that the results are biased by an increase in the acute otitis media diagnosis among children going to the nursery, because the present study is part of a large cohort study on childhood infections and bronchial obstruction up to the age of 2 years. The information on the outcome in the different contact categories was likely to be comparable for several reasons. First, there is no reason to believe that children's daycare practice or bedroom arrangements would affect the diagnosis of acute otitis media. Second, because the cohort was not primarily designed to study risk factors for acute otitis media 
alone, the participants were not aware of these specific factors when the questionnaire was returned. Thirdly, the use of questionnaires at only six month intervals minimises the possibility for recall bias. Finally, possible confounding caused by socioeconomic status, breast feeding, and maternal smoking were adjusted for in the analyses.

CONCLUSIONS

The most important risk factors for early acute otitis media were siblings in daycare and a large number of children in the daycare setting. These observations suggest that children in daycare are exposed to infectious agents which are then transmitted to the infant at home. The results are in accordance with our hypothesis that secondary as well as primary contacts play a role in the transmission of pathogens mediating acute otitis media. We suggest that this increase in morbidity should be considered in public planning of daycare arrangements for young children. Furthermore, because acute otitis media in infancy is associated with later development of recurrent acute otitis media, ${ }^{3}$ high risk infants should be followed up by the physician after an early episode of acute otitis media.
This research is supported, in part, by grants from the Norwegian Research Council.

1 Ingvarsson L, Lundgren K, Olofsson B. Epidemiology of acute otitis media in children in an urban population. Auris Nasus Larynx 1985;12(suppl 1):S105-7.

2 Klein JO. Epidemiology of otitis media. Pediatr Infect Dis $\mathcal{J}$ 1989;8:S9.

3 Giebink GS. Preventing otitis media. Ann Otol Rhinol Laryngol 1994;163:20- 3.

4 Klein JO. Hereditary and environmental factors in otitis media. Ann Otol Rhinol Laryngol 1990;99:46-7.

5 Kværner K, Tambs K, Harris JR, Magnus P. Distribution and heritability of recurrent ear infections. Ann Otol Rhinol Laryngol (in press).

6 Alho OP, Koivu M, Sorri M, Rantakallio P. Risk factors for recurrent acute otitis media and respiratory infections in infancy. Int $\mathcal{F}$ Pediatr Otorhinolaryngol 1990;19:151-61.

7 Hardy AM, Fowler MG. Child care arrangements and repeated ear infections in young children. Am $\mathcal{f}$ Public repeated ear infections
Health 1993;83:1321-5.

8 Kero P, Piekkala P. Factors affecting the occurrence of acute otitis media during the first year of life. Acta Paediatr Scand 1987;76:618-23.

9 Sipilä M, Karma K, Pukander J, Timonen M, Kataja M. The Bayesian approach to the evaluation of risk factors in. acute and recurrent otitis media. Acta Otolaryngol (Stockh) 1988;106:94-101.

10 Louhiala PJ, Jaakkola N, Ruotsalainen R, Jaakkola JJK. Form of day care and respiratory infections among Finnish children. Am $\mathcal{F}$ Public Health 1995;85:1109-11.

11 Zielhuis GA, Heuvelmans Heinen EW, Rach GH, van den Broek P. Environmental risk factors for otitis media with effusion in preschool children. Scand $\mathcal{f}$ Prim Health Care 1989;7:33-8.

12 Kleinbaum DG. Logistic regression. A self-learning text. Ann Arbor: SpringerVerlag, 1994.

13 Marx J, Osguthorpe JD, Parsons G. Day care and the incidence of otitis media in young children. Otolaryngol Head Neck Surg 1995;112:695-9.

14 Pukander J, Luotonen J, Timonen M, Karma P. Risk factors affecting the occurrence of acute otitis media among 2-3-year-old urban children. Acta Otolaryngol (Stockh) 